\title{
Cardiac sarcolemmal $\mathrm{K}_{\mathrm{ATP}}$ channels: Latest twists in a questing tale!
}

\author{
Haixia Zhang, Ph.D., Thomas P. Flagg, Ph.D. ${ }^{+}$, and Colin G. Nichols, Ph.D. ${ }^{*}$ \\ Department of Cell Biology and Physiology, Washington University School of Medicine, 660 South \\ Euclid Avenue, St. Louis, MO 63110 \\ +Department of Anatomy, Physiology and Genetics, Uniformed Services University of the Health \\ Sciences, 4301 Jones Bridge Rd., C-2114, Bethesda, MD 20814
}

\begin{abstract}
Reconstitution of $\mathrm{K}_{\mathrm{ATP}}$ channel activity from coexpression of members of the pore-forming inward rectifier gene family (Kir6.1, KCNJ8, and Kir6.2 KCNJ11) with sulfonylurea receptors (SUR1, $A B C C 8$, and SUR2, $A B C C 9$ ) of the ABCC protein sub-family, has led to the elucidation of many details of channel gating and pore properties, as well as the essential roles of Kir6.2 and SUR2 subunits in generating cardiac ventricular $\mathrm{K}_{\mathrm{ATP}}$. However, despite this extensive body of knowledge, there remain significant holes in our understanding of the physiological role of the cardiac $\mathrm{K}_{\text {ATP }}$ channel, and surprising new findings keep emerging. Recent findings from genetically modified animals include the apparent insensitivity of cardiac sarcolemmal channels to nucleotide levels, and unenvisioned complexities of the subunit makeup of the cardiac channels. This topical review focuses on these new findings and considers their implications.
\end{abstract}

\section{Introduction}

From earlier indications of a $\mathrm{K}$ conductance activated by metabolic inhibition, the tale of the cardiac $\mathrm{K}_{\mathrm{ATP}}$ channel really began in 1983 with Akinori Noma's first description of "specific $\mathrm{K}^{+}$channels which are depressed by intracellular ATP $\left(\mathrm{ATP}_{\mathrm{i}}\right)$ at levels greater than 1 $\mathrm{mM}$ "[1]. Because this $\mathrm{K}_{\mathrm{ATP}}$ channel is gated directly by intracellular ATP and ADP, it is therefore a strong candidate for coupling the metabolic state of the cell with its electrical activity and hence contractility. Reconstitution of $\mathrm{K}_{\mathrm{ATP}}$ channel activity by coexpression of members of the pore-forming inward rectifier gene family (Kir6.1, KCNJ8, and Kir6.2 KCNJ11) with sulfonylurea receptors (SUR1, $A B C C 8$, and SUR2, $A B C C 9$ ) of the ABCC protein sub-family, has led to the elucidation of many details of channel gating and pore properties[2], as well as essential roles of Kir6.2 and SUR2 subunits in generating cardiac ventricular $\mathrm{K}_{\mathrm{ATP}}[3]$ and the detrimental consequences of knocking them out on the whole organism[4]. However, despite this extensive body of knowledge, there remain significant holes in our understanding of the physiological role of the cardiac $\mathrm{K}_{\mathrm{ATP}}$ channel, and surprising new findings keep emerging. Our purpose in this topical review is to focus on these new findings and to consider their implications.

\footnotetext{
(C) 2009 Elsevier Ltd. All rights reserved.

*Address all correspondence and reprint requests to CGN: Phone: (314) 362-6630, FAX: (314) 362-7463 cnichols@wustl.edu.

Publisher's Disclaimer: This is a PDF file of an unedited manuscript that has been accepted for publication. As a service to our customers we are providing this early version of the manuscript. The manuscript will undergo copyediting, typesetting, and review of the resulting proof before it is published in its final citable form. Please note that during the production process errors may be discovered which could affect the content, and all legal disclaimers that apply to the journal pertain.
} 


\section{Nucleotide-dependent regulation in vivo: Are all bets off?}

Several reviews have covered in-depth the molecular basis of cardiac $\mathrm{K}_{\mathrm{ATP}}$ channel activity and the accumulated understanding of nucleotide regulation of channel activity[2,5,6]. $\mathrm{K}_{\mathrm{ATP}}$ channels are typically half-maximally inhibited by $\sim 10-50 \mu \mathrm{M}$ ATP, which acts by binding directly to the regulatory Kir6.2 subunit, with or without $\mathrm{Mg}^{2+}$. However, they are also activated by MgATP and MgADP, which are hydrolysed (MgATP) or maintain an activated post-hydrolytic state (MgADP) that counters ATP inhibition, and leads to the prediction that higher [ATP] (in the range of $0.1-1 \mu \mathrm{M}$ ) would be necessary to cause half-maximal inhibition under physiological conditions.

The discovery that application of the phospholipid PIP $_{2}$ to the cytoplasmic side of inside-out patches causes a decrease in sensitivity to ATP $[7,8]$ demonstrates that nucleotide sensitivity is not fixed, and could be modulated by other cellular factors. This realization means that the underlying question of when $\mathrm{K}_{\mathrm{ATP}}$ channels become active will not simply be a question of what is the cellular phosphorylation potential (i.e. the [ATP]:[ADP] ratio), but the integration of this with the signals that regulate channel responsivity. Phosphorylation of recombinant $\mathrm{K}_{\mathrm{ATP}}$ channels by protein kinase $\mathrm{A}$ or $\mathrm{C}$ [9-11] modulates nucleotide sensitivity, as do fatty acyl CoA esters[12], and minute-to-minute modulation of lipid content in the cells may also regulate the channel in vivo[13]. Interestingly, an early study of ATP inhibition of cardiac $\mathrm{K}_{\mathrm{ATP}}$ channels revealed $\mathrm{K}_{1 / 2}$ values ranging from 9-580 $\mu \mathrm{M}$ in 102 individual excised patches [14], illustrating the very marked patch-to-patch variability that is present. This variability is likely to reflect at least in part the complex regulation of nucleotide sensitivity by ambient factors, including the level of PIP2 and other activatory lipids[7,15]. However, it is also possible that the physical make-up of the individual channels varies, and that, as discussed below, there could be varying numbers of SUR subunits associated with each channel[16,17].

In experiments where $\mathrm{K}_{\mathrm{ATP}}$ was activated in isolated cardiac myocytes by anoxia, the duration of channel activity was short-lived declining in parallel with a fall in the levels of PIP and $\mathrm{PIP}_{2}$, suggesting that the levels of these two phospholipids act in concert with the intracellular nucleotides to control channel function[18]. Such data illustrate the lability of nucleotide inhibition in the intact cell, but even the relevance of nucleotide sensitivity to physiological activation of the channels might be questioned in light of recent findings regarding the in vivo consequences of channel mutations. Many mutations in the pore-forming Kir6.2 subunit have now been identified as causal in human neonatal diabetes mellitus (NDM), a very severe form of diabetes that typically occurs within the first days or weeks of life[19,20]. All of the identified Kir6.2 mutations result in a reduced channel sensitivity to ATP inhibition, in recombinant channels, leading to channel activation at elevated [glucose], maintained hyperpolarization of pancreatic islet $\beta$-cells, and electrical inexcitability, with consequent inhibition of insulin secretion[20]. The same pore-forming Kir6.2 subunit is present in the heart and pancreas, and hence cardiac $\mathrm{K}_{\mathrm{ATP}}$ channels should also be ATP-insensitive, yet there are no reports of any cardiac abnormalities in NDM patients. Moreover, in transgenic mice that express an ATP-insensitive Kir6.2 subunit (Kir6.2[ $\Delta \mathrm{N} 30, \mathrm{~K} 185 \mathrm{Q}])$ in the heart, sarcolemmal $\mathrm{K}_{\mathrm{ATP}}$ channels are extremely insensitive to ATP-dependent inhibition $\left(\mathrm{K}_{1 / 2}=1.4 \mu \mathrm{M}\right.$ c.f. 25 $\mu \mathrm{M}$ in WT), yet still remain essentially closed in intact cells[21,22]. As $\mathrm{K}_{\mathrm{ATP}}$ channels have a higher density than other sarcolemmal $\mathrm{K}^{+}$channels, opening of as few as $1 \%$ of $\mathrm{K}_{\mathrm{ATP}}$ channels is expected to shorten cardiac action potential by about 50\%, and multiple studies[23-27] predict that this dramatic reduction of ATP sensitivity should ensure that channels are active enough to significantly shorten the action potential in normal conditions, yet the action potential duration is unaffected[21]. Clearly something other than nucleotide sensitivity is at play. 


\section{Channel subunit expression in the heart: Could it get more complicated?}

In order to probe the significance of channel composition in $\mathrm{K}_{\mathrm{ATP}}$ function in cardiac myocytes, not only the ATP-insensitive Kir6.2 subunit (Kir6.2[ $\Delta$ N30,K185Q][22], but also SUR2A or SUR1[28] subunits have been overexpressed under cardiac alpha-MHC control. In each case, cardiac function is only minimally affected; in the Kir6.2[ $\Delta \mathrm{N} 30, \mathrm{~K} 185 \mathrm{Q}]$ transgenics there is a very small increase in background $\mathrm{K}_{\mathrm{ATP}}$, although this is balanced by a 'pre-stimulated' $\mathrm{Ca}$ current $[21,22]$. Conceivably this reflects an intrinsic compensatory mechanism; i.e. shortening of the action potential being compensated by enhanced Ca current, although underlying signaling processes are unknown. Overexpression of either SUR1 or SUR2A is without effect on the ECG, other than a consistent P-R prolongation in SUR1-overexpressing hearts[28]. Surprisingly, overexpression of any single one of these subunits also significantly suppresses sarcolemmal $\mathrm{K}_{\mathrm{ATP}}$ channel density[22,28]. One possible explanation is that overexpressed SUR1, SUR2A or Kir6.2 subunits interact with endogenous subunits, and thereby disrupt the stoichiometry of the channel[29] and then may not reach the plasma membrane[16,30]. A simple resolution to this would seem to be that co-overexpression of both subunits (i.e. by crossing the two animals) should restore appropriate stoichiometry of expression, leading to a high density of ATP-insensitive channels in the sarcolemma. The dramatic result, however, is an even greater suppression of total channel density[31], and a whole constellation of arrhythmias, leading to sudden death. Not only does this surprising result tell us that altered $\mathrm{K}_{\mathrm{ATP}}$ channels can have profound - but unexplained - effects on electrical activity, but that there is something very specific required for 'correct' expression of the two subunits. A clue may be found in the fact that endogenous Kir6 and SUR genes are immediately adjacent. Although perhaps heretical to suggest, it may be that common elements of gene regulation ensure that both are normally transcribed with temporal or spatial coordination, leading to correct assembly at a very early stage of synthesis, and that this coordination is absent when transgenes are exogenously expressed under alpha-MHC promoter control.

Another question is exactly which subunits are expressed in different regions of the heart. The pancreatic $\beta$-cell $\mathrm{K}_{\mathrm{ATP}}$ channel is formed as a complex of four Kir6.2 subunits each associated with one SUR1 subunit[29,32]. Together with studies of gene knockout mice (which show that Kir6.2 and SUR2 genes are essential for normal ventricular $\mathrm{K}_{\text {ATP }}$ currents, whereas KATP currents are unaffected in ventricular myocytes from SUR1 or Kir6.1 knockout animals[6]), early studies of recombinant channel pharmacology[33,34] led to the widely accepted notion that the sarcolemmal $\mathrm{K}_{\text {ATP }}$ channel is a heteromultimer of Kir6.2 and SUR2A, presumably with the same octameric arrangement. However, several studies have demonstrated that both Kir6 subunits (Kir6.1 and Kir6.2) and both SUR subunits (SUR1 and SUR2A) are expressed in the heart[35-37]. Dominant negative coexpression strategies demonstrate that Kir6.1 and Kir6.2 may assemble into functional channel complexes[38], and in some studies[36], dominant negative Kir6.1 subunits suppress sarcolemmal $\mathrm{K}_{\mathrm{ATP}}$ currents[39]. The idea that SUR2 is essential for ventricular $\mathrm{K}_{\mathrm{ATP}}$ is also muddied by the finding that some $\mathrm{K}_{\mathrm{ATP}}$ channels are still present in SUR ${ }^{-/-}$myocytes[40]. In this case, it is noteworthy that Kir6.2 channels have been shown to be present at the surface membrane in recombinant cells, in the complete absence of expressed SUR subunits[16,17,41], albeit at lower levels than are found with SUR subunits expressed. These channels are less sensitive to ATP inhibition than channels associated with SUR subunits, but lack Mg-nucleotide activation[41] It remains a possibility that an octameric arrangement is not absolutely obligatory, and that variations in channel structure at this level may influence channel activation. However, antisense oligonucleotides specific for either SUR1 or SUR2A/B suppress $\mathrm{K}_{\mathrm{ATP}}$ current in neonatal rat ventricular myocytes, which suggests that SUR1 might also participate in forming the channel, either alone or in conjunction with SUR2A[42], and recombinant channel studies demonstrate that within a single channel, more than one Kir6.x or SURx subunit can clearly co-exist[38,43-46]. 
Definitive proof that SUR1 is a significant component of sarcolemmal $\mathrm{K}_{\mathrm{ATP}}$ channels comes from recent study of SUR1 knockout $\left(\mathrm{SUR}^{-/-}\right)$animals[47]. A key finding is that while $\mathrm{K}_{\mathrm{ATP}}$ currents appear normal in SUR $1^{-/-}$ventricular myocytes, these currents are abolished in SUR $1^{-1-}$ atrial myocytes. Differential pharmacological properties of wild type atrial and ventricular $\mathrm{K}_{\mathrm{ATP}}$ channels are consistent with atrial channels forming as a heteromultimer of SUR1 and Kir6.2, whereas ventricular $\mathrm{K}_{\mathrm{ATP}}$ channel is a heteromultimer of SUR2A and Kir6.2. It is not yet clear how generalizable this finding is to other species; diazoxide activation of $\mathrm{K}_{\mathrm{ATP}}$ in myocytes of other rodent species[37,48] and in larger animals[49] suggests that SUR1 and SUR2 may be involved in both ventricular and atrial channels. However, it does raise the important issue of differential pathophysiological roles and regulation in different regions of the heart that may need to be considered when choosing sulfonylurea therapy, as well as for understanding the role of diazoxide in preconditioning.

\section{$\mathrm{K}_{\mathrm{ATP}}$ channels in ischemia: What are they good for?}

Under normal metabolic conditions, sarcolemmal $\mathrm{K}_{\mathrm{ATP}}$ channels are predominantly closed, and they do not significantly contribute to cell excitability. However, these channels will open when exposed to a severe metabolic stress such as anoxia, metabolic inhibition or ischemia. By shortening the action potential, calcium entry is reduced, and consequently myocyte contraction fails[50]. By reducing $\mathrm{Ca}^{2+}$ entry, the energy stores that would otherwise be used up in the contracting cell would be preserved and $\mathrm{Ca}^{2+}$ overload will be minimized, protecting the cell. Such a preservation 'strategy' is of course self-limiting, since if too many myocytes stop contracting, the heart stops pumping and the animal will die, but it seems a reasonable, if unproven, idea that temporary protection of a small number of cells, or region of the heart, against the damage of Ca-overload during ischemia, is likely to be operable in the heart.

In support of the idea that activation of sarcolemmal $\mathrm{K}_{\mathrm{ATP}}$ is protective during ischemia, it has been demonstrated that $\mathrm{K}_{\mathrm{ATP}}$ channel openers enhance the preservation of ATP[51] and $\mathrm{K}_{\mathrm{ATP}}$ channel openers produce anti-ischemic effects by shortening the action potential[52]. Additional support comes from evidence that glibenclamide, a selective $\mathrm{K}_{\mathrm{ATP}}$ channel inhibitor, abolishes the anti-ischemic effects by inhibiting action potential shortening[53]. In Kir6. $2^{-1-}$ mice, sarcolemmal $\mathrm{K}_{\mathrm{ATP}}$ channels are abolished[54], and $\mathrm{K}_{\mathrm{ATP}}$ channels are reduced in density [55] in rat cardiac myocytes transfected with a dominant-negative fragment of SUR2A. In both of these studies, ischemic cardioprotection is also abolished. In parallel, moderate overexpression of SUR2A reportedly increased sarcolemmal $\mathrm{K}_{\mathrm{ATP}}$ channels and protected hearts against metabolic stress, including hypoxia and ischemia/reperfusion[56]. The general idea that $\mathrm{K}_{\mathrm{ATP}}$ activation provides cardioprotection against ischemic stress is further supported by recent evidence that Kir6. $2^{-/-}$mice exhibit impaired response to systolic overload following chronic transverse aortic constriction[57].

However, two further recent studies seem to contradict a cardioprotective role. In these studies, from independent groups, both SUR2- (SUR2 ${ }^{-l-}$ ) and SUR1-knockout (SUR1 ${ }^{-{ }^{-}}$) mice were found to be more tolerant of global ischemia-reperfusion than control mice, with reduced infarct sizes [58,59]. Since the SUR $2^{-1}$ mice have a great reduction of ventricular sarcolemmal $\mathrm{K}_{\mathrm{ATP}}$ channels, the enhanced cardioprotection is opposite the expected phenotype (i.e. impaired protection). Cardioprotection in SUR2 ${ }^{-/-}$mice might conceivably be due to the concomitant loss of the SUR2B component of vascular $\mathrm{K}_{\mathrm{ATP}}$ channels, but similar cardioprotection in SUR $1^{-1-}$ mice[59] could not be explained by such a mechanism. The SUR $2^{-/-}$animals were generated by disruption of the first nucleotide-binding domain, which might allow translation of the preceding TM0 and TM1 or following TM2 domains of the protein. Pu et al.[40] designed antibodies to epitopes in these regions and detected novel SUR2 short forms in the sizes of 28 and $68 \mathrm{kDa}$ in both WT and SUR2 ${ }^{-1-}$ hearts. These findings raise yet more questions regarding the ultimate complexity of channel makeup. 


\section{Preconditioning and sarcolemmal $\mathrm{K}_{\mathrm{ATP}}$ channels: Can an old dogma learn new tricks?}

Ischemic preconditioning refers to a phenomenon whereby brief ischemic periods improve the recovery of contractile function and reduce the size of the infarct that results from a subsequent prolonged ischemia[60]. Preconditioning can be mimicked by adenosine or acetylcholine, as well as by $\mathrm{K}_{\mathrm{ATP}}$ channel openers, such as diazoxide[52], and glibenclamide inhibits ischemic as well as adenosine- and acetylcholine-induced preconditioning[61], implicating $\mathrm{K}_{\mathrm{ATP}}$ channels in the phenomenon. However, several lines of evidence have been used to argue that channels in the sarcolemma are not responsible: (1) preconditioning effects of $\mathrm{K}_{\mathrm{ATP}}$ channel openers may not require shortening of the action potential[62,63]; (2) the channel opener diazoxide mimics ischemic preconditioning[64], even though diazoxide is relatively ineffective at opening ventricular sarcolemmal $\mathrm{K}_{\mathrm{ATP}}$ channels[47,65]. On the other hand, diazoxide is reportedly effective at stimulating a so-called 'mitoK $\mathrm{ATP}_{\text {' }}$ channel that was identified in the mitochondria[66]. Based on this, and the finding that (3) 5-hydroxydecanoic acid effectively abolishes ischemic preconditioning[67], and is reportedly specific for

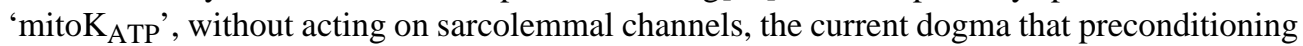

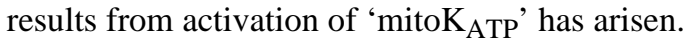

However, it is now clear that at least one central assumption is incorrect: diazoxide can open sarcolemmal $\mathrm{K}_{\mathrm{ATP}}$ channels[65] and mouse atrial sarcolemmal $\mathrm{K}_{\text {ATP }}$ channels are highly sensitive to diazoxide[47]. Although diazoxide might have an action on mitochondrial succinate dehydrogenase[68] or $\mathrm{F}_{1} \mathrm{~F}_{0}$ ATPase function (which in turn could alter sarcolemmal function through nucleotide levels), the above findings require at the least that the use of diazoxide in preconditioning studies be interpreted with caution. Data from hearts with transgenically manipulated sarcolemmal $\mathrm{K}_{\mathrm{ATP}}$ subunits also points to a role of sarcolemmal $\mathrm{K}_{\mathrm{ATP}}$ in preconditioning: even though the effects of diazoxide on flavoprotein fluorescence are preserved[54], ischemic- and diazoxide-induced preconditioning are both abolished in hearts from Kir6. $2^{-/-}$animals $[54,69]$ as well as from animals with transgenic overexpression of ATP-insensitive Kir6.2 subunits[70], and in rat cardiac myocytes transfected with a dominant-negative fragment of SUR2A[55]. There is also little evidence that any of these sarcolemmal subunits are present in the mitochondria[71]. More important, the existence of conventional $\mathrm{K}_{\mathrm{ATP}}$ channels in mitochondria has been questioned[72], as has the specificity of commercial antibodies used to probe for such components[73]. At this point it is probably fair to say that this muddied picture leaves open the possibility that sarcolemmal $\mathrm{K}_{\mathrm{ATP}}$ channels are the relevant ' $\mathrm{K}_{\mathrm{ATP}}$ players' in preconditioning.

\section{Conclusions}

Four years ago, we summarized a topical review of sarcolemmal $\mathrm{K}_{\mathrm{ATP}}$ channels with the statement that we remain 'largely in the dark regarding the true physiological determinants, and relevance of sarcolemmal $\mathrm{K}_{\mathrm{ATP}}$ activity' [3]. In many ways, subsequent developments have only served to make us realize just how large a darkness we are in - ATP-sensitivity may not really be the key physiological regulator of channel activity, we now realize that the subunit make-up of sarcolemmal channels may be more complex and labile than we thought, and the existence of mitoK $\mathrm{K}_{\mathrm{ATP}}$ and the roles of sarcolemmal versus mitochondrial $\mathrm{K}_{\mathrm{ATP}}$ channels in preconditioning are really not clear. At the same time, however, new studies of the whole animal consequences of manipulation of cardiac $\mathrm{K}_{\mathrm{ATP}}$ subunits have continued to reveal dramatic roles in arrhythmia generation, and in the animal responsivity to cardiac and systemic stress. The questing tale of cardiac $\mathrm{K}_{\mathrm{ATP}}$ channel function continues! 


\section{References}

1. Noma A. ATP-regulated K+ channels in cardiac muscle. Nature 1983;305(5930):147-8. [PubMed: 6310409]

2. Nichols CG. KATP channels as molecular sensors of cellular metabolism. Nature 2006;440(7083): 470-6. [PubMed: 16554807]

3. Flagg TP, Nichols C. Sarcolemmal K(ATP) channels: what do we really know? Journal of Molecular \& Cellular Cardiology 2005;39:61-70. [PubMed: 15978903]

4. Kane GC, Liu XK, Yamada S, Olson TM, Terzic A. Cardiac KATP channels in health and disease. J Mol Cell Cardiol Jun;2005 38(6):937-43. [PubMed: 15910878]

5. Nichols CG, Lederer WJ. Adenosine triphosphate-sensitive potassium channels in the cardiovascular system. Am J Physiol 1991;261(6 Pt 2):H1675-86. [PubMed: 1750525]

6. Seino S, Miki T. Gene targeting approach to clarification of ion channel function: studies of Kir6.x null mice. Journal of Physiology 2004;554(Pt 2):295-300. [PubMed: 12826653]

7. Shyng SL, Nichols CG. Membrane phospholipid control of nucleotide sensitivity of KATP channels. Science 1998;282(5391):1138-41. [PubMed: 9804554]

8. Baukrowitz T, Schulte U, Oliver D, Herlitze S, Krauter T, Tucker SJ, et al. PIP2 and PIP as determinants for ATP inhibition of KATP channels. Science 1998;282(5391):1141-4. 282:1059-60. [PubMed: 9804555]

9. Beguin P, Nagashima K, Nishimura M, Gonoi T, Seino S. PKA-mediated phosphorylation of the human K(ATP) channel: separate roles of Kir6.2 and SUR1 subunit phosphorylation. EMBO Journal 1999;18 (17):4722-32. [PubMed: 10469651]

10. Lin YF, Jan YN, Jan LY. Regulation of ATP-sensitive potassium channel function by protein kinase A-mediated phosphorylation in transfected HEK293 cells. Embo J 2000;19(5):942-55. [PubMed: 10698936]

11. Light PE, Bladen C, Winkfein RJ, Walsh MP, French RJ. Molecular basis of protein kinase C-induced activation of ATP-sensitive potassium channels. Proc Natl Acad Sci U S A 2000;97(16):9058-63. [PubMed: 10908656]

12. Liu GX, Hanley PJ, Ray J, Daut J. Long-chain acyl-coenzyme A esters and fatty acids directly link metabolism to K(ATP) channels in the heart. Circ Res 2001;88(9):918-24. [PubMed: 11349001]

13. Xie LH, Horie M, Takano M. Phospholipase C-linked receptors regulate the ATP-sensitive potassium channel by means of phosphatidylinositol 4,5-bisphosphate metabolism. Proceedings of the National Academy of Sciences of the United States of America 1999;96(26):15292-7. [PubMed: 10611378]

14. Findlay I. ATP-sensitive $\mathrm{K}+$ channels in rat ventricular myocytes are blocked and inactivated by internal divalent cations. Pflugers Archiv European Journal of Physiology 1987;410(3):313-20. [PubMed: 2446256]

15. Xie LH, Takano M, Kakei M, Okamura M, Noma A. Wortmannin, an inhibitor of phosphatidylinositol kinases, blocks the MgATP-dependent recovery of Kir6.2/SUR2A channels. Journal of Physiology 1999;514(Pt 3):655-65. [PubMed: 9882737]

16. Zerangue N, Schwappach B, Jan YN, Jan LY. A new ER trafficking signal regulates the subunit stoichiometry of plasma membrane K(ATP) channels. Neuron 1999;22(3):537-48. [PubMed: 10197533]

17. John SA, Monck JR, Weiss JN, Ribalet B. The sulphonylurea receptor SUR1 regulates ATP-sensitive mouse Kir6.2 K+ channels linked to the green fluorescent protein in human embryonic kidney cells (HEK 293). Journal of Physiology 1998;510(Pt 2):333-45. [PubMed: 9705987]

18. Loussouarn G, Pike LJ, Ashcroft FM, Makhina EN, Nichols CG. Dynamic sensitivity of ATPsensitive K(+) channels to ATP. J Biol Chem 2001;276(31):29098-103. [PubMed: 11395495]

19. Ashcroft FM. K(ATP) channels and insulin secretion: a key role in health and disease. Biochemical Society Transactions 2006;34(Pt 2):243-6. [PubMed: 16545085]

20. Koster JC, Permutt MA, Nichols CG. Diabetes and insulin secretion: the ATP-sensitive K+ channel (K ATP) connection. Diabetes 2005;54(11):3065-72. [PubMed: 16249427]

21. Flagg TP, Charpentier F, Manning-Fox J, Remedi MS, Enkvetchakul D, Lopatin A, et al. Remodeling of excitation-contraction coupling in transgenic mice expressing ATP-insensitive sarcolemmal 
KATP channels. American Journal of Physiology - Heart \& Circulatory Physiology 2004;286 (4):H1361-9. [PubMed: 14656703]

22. Koster JC, Knopp A, Flagg TP, Markova KP, Sha Q, Enkvetchakul D, et al. Tolerance for ATPInsensitive $\mathrm{K}_{\text {ATP }}$ Channels in Transgenic Mice. Circulation Research 2001;89 In Press.

23. Knopp A, Thierfelder S, Koopmann R, Biskup C, Bohle T, Benndorf K. Anoxia generates rapid and massive opening of KATP channels in ventricular cardiac myocytes. Cardiovasc Res 1999;41(3): 629-40. [PubMed: 10435035]

24. Nichols CG, Lederer WJ. The regulation of ATP-sensitive $\mathrm{K}+$ channel activity in intact and permeabilized rat ventricular myocytes. Journal of Physiology London 1990;423(91):91-110. [PubMed: 2388163]

25. Ripoll C, Lederer WJ, Nichols CG. Modulation of ATP-sensitive K+ channel activity and contractile behavior in mammalian ventricle by the potassium channel openers cromakalim and RP49356. Journal of Pharmacology \& Experimental Therapeutics 1990;255(2):429-35. [PubMed: 2243335]

26. Weiss JN, Venkatesh N, Lamp ST. ATP-sensitive K+ channels and cellular K+ loss in hypoxic and ischaemic mammalian ventricle. Journal of Physiology 1992;447(649):649-73. [PubMed: 1593462]

27. Shaw RM, Rudy Y. Electrophysiologic effects of acute myocardial ischemia. A mechanistic investigation of action potential conduction and conduction failure. Circ Res 1997;80(1):124-38. [PubMed: 8978331]

28. Flagg TP, Remedi MS, Masia R, McLerie M, Lopatin A, Nichols C. Transgenic overexpression of SUR1 in the heart exerts dominant negative effects on sarcolemmal K ATP. Journal of Molecular \& Cellular Cardiology 2005;39:647-56. [PubMed: 16099470]

29. Shyng S, Nichols CG. Octameric stoichiometry of the KATP channel complex. J Gen Physiol 1997;110(6):655-64. [PubMed: 9382894]

30. Schwappach B, Zerangue N, Jan YN, Jan LY. Molecular basis for K(ATP) assembly: transmembrane interactions mediate association of a K+ channel with an ABC transporter. Neuron 2000;26(1):15567. [PubMed: 10798400]

31. Flagg TP, Patton B, Masia R, Mansfield C, Lopatin AN, Yamada KA, et al. Arrhythmia susceptibility and premature death in transgenic mice overexpressing both SUR1 and Kir6.2[DeltaN30,K185Q] in the heart. Am J Physiol Heart Circ Physiol Jul;2007 293(1):H836-45. [PubMed: 17449558]

32. Clement, JPt; Kunjilwar, K.; Gonzalez, G.; Schwanstecher, M.; Panten, U.; Aguilar-Bryan, L., et al. Association and stoichiometry of K(ATP) channel subunits. Neuron 1997;18(5):827-38. [PubMed: 9182806]

33. Inagaki N, Tsuura Y, Namba N, Masuda K, Gonoi T, Horie M, et al. Cloning and functional characterization of a novel ATP-sensitive potassium channel ubiquitously expressed in rat tissues, including pancreatic islets, pituitary, skeletal muscle, and heart. Journal of Biological Chemistry 1995;270(11):5691-4. [PubMed: 7890693]

34. Babenko AP, Gonzalez G, Aguilar-Bryan L, Bryan J. Reconstituted human cardiac KATP channels: functional identity with the native channels from the sarcolemma of human ventricular cells. Circ Res 1998;83(11):1132-43. [PubMed: 9831708]

35. Singh H, Hudman D, Lawrence CL, Rainbow RD, Lodwick D, Norman RI. Distribution of Kir6.0 and SUR2 ATP-sensitive potassium channel subunits in isolated ventricular myocytes. Journal of Molecular \& Cellular Cardiology 2003;35(5):445-59. [see comment]. [PubMed: 12738227]

36. van Bever L, Poitry S, Faure C, Norman RI, Roatti A, Baertschi AJ. Pore loop-mutated rat KIR6.1 and KIR6.2 suppress KATP current in rat cardiomyocytes. American Journal of Physiology - Heart \& Circulatory Physiology 2004;287(2):850-9.

37. Isidoro Tavares N, Philip-Couderc P, Papageorgiou I, Baertschi AJ, Lerch R, Montessuit C. Expression and function of ATP-dependent potassium channels in late post-infarction remodeling. Journal of Molecular and Cellular Cardiology 2007;42(6):1016-25. [PubMed: 17512536]

38. Cui Y, Giblin JP, Clapp LH, Tinker A. A mechanism for ATP-sensitive potassium channel diversity: Functional coassembly of two pore-forming subunits. Proc Natl Acad Sci U S A 2001;98(2):72934. [PubMed: 11136227]

39. Pountney DJ, Sun ZQ, Porter LM, Nitabach MN, Nakamura TY, Holmes D, et al. Is the molecular composition of K(ATP) channels more complex than originally thought? J Mol Cell Cardiol Aug; 2001 33(8):1541-6. [PubMed: 11448141] 
40. Pu J-L, Ye B, Kroboth SL, McNally EM, Makielski JC, Shi N-Q. Cardiac sulfonylurea receptor short form-based channels confer a glibenclamide-insensitive KATP activity. Journal of Molecular and Cellular Cardiology 2008;44(1):188-200. [PubMed: 18001767]

41. Tucker SJ, Gribble FM, Zhao C, Trapp S, Ashcroft FM. Truncation of Kir6.2 produces ATP-sensitive $\mathrm{K}+$ channels in the absence of the sulphonylurea receptor. Nature 1997;387(6629):179-83. [PubMed: 9144288]

42. Yokoshiki H, Sunagawa M, Seki T, Sperelakis N. Antisense oligodeoxynucleotides of sulfonylurea receptors inhibit ATP-sensitive $\mathrm{K}+$ channels in cultured neonatal rat ventricular cells. Pflugers Archiv European Journal of Physiology 1999;437(3):400-8. [PubMed: 9914396]

43. Chan KW, Wheeler A, Csanady L. Sulfonylurea receptors type 1 and 2A randomly assemble to form heteromeric KATP channels of mixed subunit composition. J Gen Physiol Jan;2008 131(1):43-58. [PubMed: 18079561]

44. Cheng WW, Tong A, Flagg TP, Nichols CG. Random assembly of SUR subunits in K(ATP) channel complexes. Channels (Austin) Jan-Feb;2008 2(1):34-8. [PubMed: 18690055]

45. Wheeler A, Wang C, Yang K, Fang K, Davis K, Styer AM, et al. Coassembly of Different Sulfonylurea Receptor Subtypes Extends the Phenotypic Diversity of ATP-sensitive Potassium (KATP) Channels. Mol Pharmacol November 1;2008 74(5):1333-44. 2008. [PubMed: 18723823]

46. Kono Y, Horie M, Takano M, Otani H, Xie L, Akao M, et al. The properties of the Kir6.1-6.2 tandem channel co-expressed with SUR2A. Pflugers Arch 2000;440:692-8. [PubMed: 11007308]

47. Flagg TP, Kurata HT, Masia R, Caputa G, Magnuson MA, Lefer DJ, et al. Differential structure of atrial and ventricular KATP: atrial KATP channels require SUR1. Circ Res Dec 5;2008 103(12): 1458-65. [PubMed: 18974387]

48. Kocic I, Gruchala M, Petrusewicz J. Selective inhibition of pinacidil effects by estrogen in guinea pig heart. Int J Cardiol Jun 7;2006 110(1):22-6. [PubMed: 16095733]

49. Mull KP, Debnam Q, Kabir SM, Bhattacharyya ML. Role of action potential shortening in the prevention of arrhythmias in canine cardiac tissue. Clin Exp Pharmacol Physiol Dec;1999 26(12): 964-9. [PubMed: 10626063]

50. Lederer WJ, Nichols CG, Smith GL. The mechanism of early contractile failure of isolated rat ventricular myocytes subjected to complete metabolic inhibition. J Physiol 1989;413:329-49. [PubMed: 2600854]

51. McPherson CD, Pierce GN, Cole WC. Ischemic cardioprotection by ATP-sensitive K+ channels involves high-energy phosphate preservation. Am J Physiol Nov;1993 265(5 Pt 2):H1809-18. [PubMed: 8238595]

52. Grover GJ, Garlid KD. ATP-Sensitive potassium channels: a review of their cardioprotective pharmacology. J Mol Cell Cardiol 2000;32(4):677-95. [PubMed: 10756123]

53. Yao Z, Gross GJ. Acetylcholine mimics ischemic preconditioning via a glibenclamide-sensitive mechanism in dogs. American Journal of Physiology. 1993

54. Suzuki M, Sasaki N, Miki T, Sakamoto N, Ohmoto-Sekine Y, Tamagawa M, et al. Role of sarcolemmal K(ATP) channels in cardioprotection against ischemia/reperfusion injury in mice. $\mathrm{J}$ Clin Invest 2002;109(4):509-16. [PubMed: 11854323]

55. Rainbow RD, Lodwick D, Hudman D, Davies NW, Norman RI, Standen NB. SUR2A C-terminal fragments reduce KATP currents and ischaemic tolerance of rat cardiac myocytes. J Physiol Jun 15;2004 557(Pt 3):785-94. [PubMed: 15020694]

56. Du Q, Jovanovic S, Clelland A, Sukhodub A, Budas G, Phelan K, et al. Overexpression of SUR2A generates a cardiac phenotype resistant to ischemia. FASEB J Jun;2006 20(8):1131-41. [PubMed: 16770012]

57. Hu X, Xu X, Huang Y, Fassett J, Flagg TP, Zhang Y, et al. Disruption of Sarcolemmal ATP-Sensitive Potassium Channel Activity Impairs the Cardiac Response to Systolic Overload. Circ Res October 24;2008 103(9):1009-17. 2008. [PubMed: 18802029]

58. Stoller D, Kakkar R, Smelley M, Chalupsky K, Earley JU, Shi NQ, et al. Mice lacking sulfonylurea receptor 2 (SUR2) ATP-sensitive potassium channels are resistant to acute cardiovascular stress. J Mol Cell Cardiol Oct;2007 43(4):445-54. [PubMed: 17765261] 
59. Elrod JW, Harrell M, Flagg TP, Gundewar S, Magnuson MA, Nichols CG, et al. Role of sulfonylurea receptor type 1 subunits of ATP-sensitive potassium channels in myocardial ischemia/reperfusion injury. Circulation Mar 18;2008 117(11):1405-13. [PubMed: 18316485]

60. Murry C, Jennings R, Reimer K. Preconditioning with ischemia: a delay of lethal cell injury in ischemic myocardium. Circulation November 1;1986 74(5):1124-36. 1986. [PubMed: 3769170]

61. Gross GJ, Auchampach JA. Blockade of ATP-sensitive potassium channels prevents myocardial preconditioning in dogs. Circulation Research 1992;70(2):223-33. [PubMed: 1310443]

62. Yao Z, Gross G. Effects of the KATP channel opener bimakalim on coronary blood flow, monophasic action potential duration, and infarct size in dogs. Circulation April 1;1994 89(4):1769-75. 1994. [PubMed: 8149542]

63. Hamada K, Yamazaki J, Nagao T. Shortening of Action Potential Duration is not Prerequisite for Cardiac Protection by Ischemic Preconditioning or a KATPChannel Opener. Journal of Molecular and Cellular Cardiology 1998;30(7):1369-79. [PubMed: 9710805]

64. Garlid KD, Paucek P, Yarov-Yarovoy V, Murray HN, Darbenzio RB, D'Alonzo AJ, et al. Cardioprotective effect of diazoxide and its interaction with mitochondrial ATP-sensitive K+ channels. Possible mechanism of cardioprotection. Circ Res 1997;81(6):1072-82. [PubMed: 9400389]

65. D'Hahan N, Moreau C, Prost AL, Jacquet H, Alekseev AE, Terzic A, et al. Pharmacological plasticity of cardiac ATP-sensitive potassium channels toward diazoxide revealed by ADP. Proceedings of the National Academy of Sciences of the United States of America 1999;96(21):12162-7. [PubMed: 10518593]

66. Inoue I, Nagase H, Kishi K, Higuti T. ATP-sensitive K+ channel in the mitochondrial inner membrane. Nature 1991;352(6332):244-7. [PubMed: 1857420]

67. Liu Y, Sato T, O'Rourke B, Marban E. Mitochondrial ATP-dependent potassium channels: novel effectors of cardioprotection? Circulation 1998;97(24):2463-9. [PubMed: 9641699]

68. Hanley PJ, Mickel M, Loffler M, Brandt U, Daut J. K(ATP) channel-independent targets of diazoxide and 5-hydroxydecanoate in the heart. J Physiol Aug 1;2002 542(Pt 3):735-41. [PubMed: 12154175]

69. Suzuki M, Saito T, Sato T, Tamagawa M, Miki T, Seino S, et al. Cardioprotective Effect of Diazoxide Is Mediated by Activation of Sarcolemmal but Not Mitochondrial ATP-Sensitive Potassium Channels in Mice. Circulation February 11;2003 107(5):682-5. 2003. [PubMed: 12578868]

70. Rajashree R, Koster JC, Markova KP, Nichols CG, Hofmann PA. Contractility and ischemic response of hearts from transgenic mice with altered sarcolemmal K(ATP) channels. American Journal of Physiology - Heart \& Circulatory Physiology 2002;283(2):584-90.

71. Hu H, Sato T, Seharaseyon J, Liu Y, Johns DC, O'Rourke B, et al. Pharmacological and histochemical distinctions between molecularly defined sarcolemmal KATP channels and native cardiac mitochondrial KATP channels. Mol Pharmacol 1999;55(6):1000-5. [PubMed: 10347240]

72. Morrissey A, Rosner E, Lanning J, Parachuru L, Chowdhury PD, Han S, et al. Immunolocalization of KATP channel subunits in mouse and rat cardiac myocytes and the coronary vasculature. BMC Physiology 2005;5:1. [PubMed: 15647111]

73. Brian Foster D, Rucker JJ, Marbán E. Is Kir6.1 a subunit of mitoKATP? Biochemical and Biophysical Research Communications 2008;366(3):649-56. [PubMed: 18068667] 